The trachea, when moderately extended, measures 10 inches in length, and is furnished with strong lateral or contractor muscles, a pair of cleidotracheal, and a pair of more slender sterno-tracheal. Its diameter at the upper part is $4 \frac{1}{2}$ twelfths, it gradually contracts to $3 \frac{1}{2}$ twelfths, enlarges to $4 \frac{1}{2}$ twelfths, and at the distance of $7 \frac{1}{4}$ inches from the upper extremity, forms a dilatation about an inch in length, and $\frac{7}{12}$ in its greatest diameter, but composed of distinct rings, then contracts to $\frac{3}{12}$, and ends in a bony and membranous expansion, forming on the left side an irregular thin disk, convex towards the right, and flattened towards the left, where it is membranous. The expansions of the trachea are thus similar to those of the Redbreasted Merganser, but of less extent; the rings are of equal breadth on both sides, but alternately overlap each other, one side being partially concealed by the corresponding sides of those above and below it, while the other stands exposed. The lower larynx is formed of ten united rings, together with the bony and membranous expansion described. The tracheal rings, rather broad and osseous, are 118; the half-rings of the bronchi about 16 .

\title{
RED-HEADED DUCK.
}

+Fuligula Ferina, Linn.

\section{Plate CCCXCVI.-Male and Female.}

At New Orleans, this bird is commonly known by the name of "Dos Gris." It arrives there in great flocks, about the first of November, and departs late in April, or in the beginning of May. On the lakes Borgne, St. John, and Ponchartrain, it is very abundant, keeping in large flocks, separate from the other species. In that part of the country its food consists of small fishes, in pursuit of which it is seen constantly diving. It is caught in different sorts of nets, and easily kept in confinement, feeding greedily on Indian corn, whether entire or crushed by the millstone. In 1816, many thousands of these Ducks as well as others of different species, were caught in nets by a. Frenchman, who usually sent them alive to market in cages from the narrows of the Lakes, especially from those called " $\mathrm{La}$ 
pointe aux herbes," and the "Isle aux pins." So many of them, however, were procured by this man, that he after awhile gave up sending them alive, on account of the great difficulty he encountered in procuring a sufficient number of cages for their accommodation.

Although Dr. Richardson informs us that this species breeds "in all parts of the Fur Countries, from the fiftieth parallel to their most northern limits," I saw none of these birds during the spring and summer months which I spent on the coast of Labrador. I was equally unsuccessful in my search for it in Newfoundland. Indeed, I have never observed it eastward of the State of Massachusetts, although from thence it is more and more abundant the farther south you proceed, until you reach the tributaries of the Mississippi. Beyond the mouths of that river, these birds are rarely seen; and when I was there in April 1837, none were observed by my party or myself after we had left the South-west Pass on our way westward. In Texas none were even heard of. From these circumstances I have inferred that, along with several other species, the Red-headed Duck reaches the Middle and Southern States by passing overland or following our great streams, such as the Ohio, Missouri, and Mississippi, westward, and the North river, and others eastward, both in its vernal and autumnal migrations. This I am the more inclined to believe, on account of the great numbers which on such occasions I have seen in ponds in the States of Illinois, Indiana, Ohio, and Kentucky.

I found it abundant in the marshes near St. Augustine, in East Florida, on the Sth of November, 1S31, when the young males of that year had the breast and lower neck mottled with brown and blackish feathers; and yet whilst at General Hernandez's, in that district, on the 20th of December, they were in almost perfect plumage. At this latter period they were shy, and kept in company with Mallards, American Widgeons, Scaup Ducks, and Spoonbills, generally in shallow fresh-water ponds, at some distance from the sea-shore. In South Carolina, these Ducks are now much more abundant than they were twenty years ago, especially on the Santee river, where my friend Dr. Sanduel Wilson has shot many of them, as well as of the Canvass-back species.

The Red-headed Duck may be said to be equally fond of salt and fresh water, and is found in abundance, during its stay with us, on the Chesapeake Bay, especially in the month of March, when it associates with the Canvassback and other Ducks, and is offered for sale in the Baltimore markets in great numbers. There $I$ have seen them sold at 75 cents the pair, which was lower by 25 cents than their price at New Orleans in April 1837.

Although they dive much and to a great depth, while in our bays and estuaries, yet when in the shallow ponds of the interior, they are seen 
dabbling the mud along the shores, much in the manner of the Mallard; and on occasionally shooting them there, I have found their stomach crammed with young tadpoles and small water-lizards, as well as blades of the grasses growing around the banks. Nay, on several occasions, I have found pretty large acorns and beech-nuts in their throats, as well as snails, entire or broken, and fragments of the shells of various small unios, together with much gravel.

In confinement, they do not exhibit that degree of awkwardness attributed to them when on land. It is true that the habitual shortening of the neck detracts from their beauty, so that in this state they cannot be said to present a graceful appearance; yet their aspect has always been pleasing to my sight. Their notes are rough and coarse, and bear less resemblance to the cries of those species which are peculiar to fresh water than those of any other of their tribe. Their flight is performed in a hurried manner, and they start from the water pell-mell; yet they can continue very long on wing, and the motions of their pinions, especially at night, produce a clear whistling sound.

The fine pair from which I, made the two figures in the plate were given me by my friend Daniel Webster, Esq. of Boston, Massachusetts, whose talents and accomplishments are too well known to require any eulogium from me.

The flesh of this bird is generally esteemed, insomuch that many persons know no difference between it and that of the Canvass-back Duck, for which it is not unfrequently sold; but I look upon it as far inferior to that of many other Ducks. Individuals of both sexes vary much in size. On comparing American with European skins, I am unable to perceive any difference of colour or proportions indicative of specific distinction.

Red-headed Duck, Anas Ferina, Wils. Amer. Orn., vol. viii. p. 110.

Fuligula Ferina, Bonap. Syn., p. 392.

Fuligula Ferina, Swains. and Rich. F. Bor. Amer., vol. ii. p. 452.

1 Red-headed Duck or Pochard, Nutt. Man., vol. ii. p. 434.

ct Red-headed Duck, Fuligula Ferina, Aud. Orn. Biog., vol. iv. p. 198. thi

nTale, 20, 33. Female, 21, 32 $\frac{1}{2}$.

breeds throughout the Fur Countries, from which it migrates southward in early autumn. Abundant on the Chesapeake, New York Bay, Ohio, and Mississippi, with their tributaries. None seen westward of the Mississippi. Adult Male.

Bill as long as the head, deeper than broad at the base, the margins parallel, slightly dilated towards the end, which is rounded, the frontal angles rather narrow and pointed. Upper mandible with the dorsal line at

VOL. VI. 
first straight and declinate, then slightly concave, direct for a short space near the tip, where it is incurved, the ridge broad and concave at the base, narrowed at the middle, enlarged and convex at the end; the sides nearly erect at the base, becoming anteriorly more and more declinate and convex, the edges curved, with about 45 lamellæ, the unguis elliptical, and abruptly rounded at the end. Nostrils sub-medial, oblong, rather large, pervious, near the ridge, in an oblong depression covered with soft membrane. Lower mandible flattened, being but slightly convex, with the angle very long and rather narrow, the dorsal line very short and slightly convex, the erect edges with about 55 inferior lamellæ; the unguis obovate and abrupt.

Head rather large, compressed, convex above. Eyes small. Neck of moderate length, rather thick. Body full, depressed. Wings small. Feet very short, strong, placed rather far behind; tarsus very short, compressed, anteriorly with narrow scutella continuous with those of the middle toe, and having another series commencing half-way down and continuous with those of the outer toe, the rest reticulated with angular scales. Hind toe small, with an inner expanded margin or web; middle toe nearly double the length of the tarsus, outer a little shorter. Claws small, compressed, that of the first toe very small and curved, of the third toe larger and more expanded than the rest.

Plumage dense, soft, blended. Feathers of the upper part of the head small and rather compact, of the rest of the head and neck small, blended, and glossy. Wings shortish, narrow, pointed; primary quills strong, tapering, the first longest, the second almost as long, the rest rapidly diminishing; secondary quills broad and rounded, the inner elongated and tapering. Tail very short, much rounded, or wedge-shaped, of fourteen feathers.

Bill light greyish-blue, with a broad band of black at the end, and a dusky patch anterior to the nostrils. Iris orange-yellow. Head and neck all round, for more than half its length, of a rich brownish-red, glossed with carmine above. A broad belt of brownish-black occupies the lower part of the neck, and the fore part of the body, of which the posterior part is of the same colour, more extended on the back than under the tail. Back an. scapulars pale greyish-white, very minutely traversed by dark brownis grey lines; the sides and abdomen similar, the undulations gradually fadsslg away into the greyish-white of the middle of the breast; upper wing-coverts brownish-grey, the feathers faintly undulated with whitish toward the end. Primary quills brownish-grey, dusky along the outer web and at the end; secondaries ash-grey, narrowly tipped with white, the outer faintly tinged with yellow, and almost imperceptibly dotted with whitish, four or five of the inner of a purer tint, tinged with blue, and having a narrow brownishblack line along the margin; the innermost like the scapulars, but more 
dusky. Tail brownish-grey, towards the end lighter. Axillar feathers and lower wing-coverts white. Feet dull greyish-blue, the webs dusky, the claws black.

Length to end of tail 20 inches, to end of wings $18 \frac{1}{2}$, to end of claws 22; extent of wings 33 ; wing from flexure $9 \frac{2}{12}$; tail $2 \frac{8}{12}$; bill along the ridge 2 , from the tips of the frontal processes $2 \frac{4}{12}$; tarsus $1 \frac{1}{2}$, first toe and claw $\frac{10}{12}$; second toe $1 \frac{1}{1} \frac{0}{2}$, its claw $\frac{3 \frac{1}{2}}{12}$; third toe $2 \frac{5}{12}$, its claw $\frac{4}{12}$; fourth toe $2 \frac{6}{12}$, its claw $\frac{3 \frac{1}{2}}{12}$. Weight $2 \frac{1}{2}$ lbs.

Adult Female.

The female has the bill of a dusky bluish-grey, with a broad band of black at the end, and a narrow transverse blue line, narrower than in the male. Iris yellow. Feet as in the male, the head and upper part of the neck dull reddish-brown, darker above, and lighter on the fore part of the cheeks and along a streak behind the eye. The rest of the neck all round, and the upper parts in general, are dull greyish-brown, the feathers paler at their extremity; the flanks and fore part of the neck dull reddish-brown, the feathers broadly tipped with pale greyish-brown. The wings are as in the male, but of a darker tint, and without undulations. The tail as in the male. Lower wing-coverts light grey, those in the middle white; middle of breast greyish-white; hind part of abdomen light brownish-grey.

Length to end of tail 21 inches, to end of claws $23 \frac{1}{2}$; extent of wings $32 \frac{1}{2}$. Weight 2 lbs. 7 oz.

The following account of the digestive organs is taken from a British specimen, an adult male, examined by Mr. MacGillivray in March 1 s36.

The tongue is 1 inch and 10 twelfths long, $6 \frac{1}{2}$ twelfths broad, its sides furnished with two series of bristly filaments. The œsophagus is 11 inches long, with a diameter of nearly 5 twelfths at the top, 8 twelfths at the lower part of the neck. The proventriculus has a diameter of 9 twelfths; its glandules are cylindrical, and 2 twelfths long. The stomach is an extremely powerful gizzard, of an elliptical form, compressed, oblique, its length $2 \frac{1}{2}$ inches, its breadth $1 \frac{3}{4}$; its lateral muscles more than half an inch thick; the cuticular coat rather thin, but very tough, slightly rugous, with two circular thicker parts opposite the centres of the lateral muscles. The upper part forms a small sac, from which the duodenum comes off; the pylorus without valve. The intestine is 5 feet 4 inches long, narrowest in its upper part, where its diameter is 4 twelfths, widest at the middle, where it is $6 \frac{1}{2}$ twelfths, near the cœca $\frac{5}{12}$. The rectum is $5 \frac{1}{2}$ inches long, its diameter 6 twelfths; the cœca 7 inches long, nearly cylindrical, 4 twelfths in diameter, a little narrower at the commencement. 


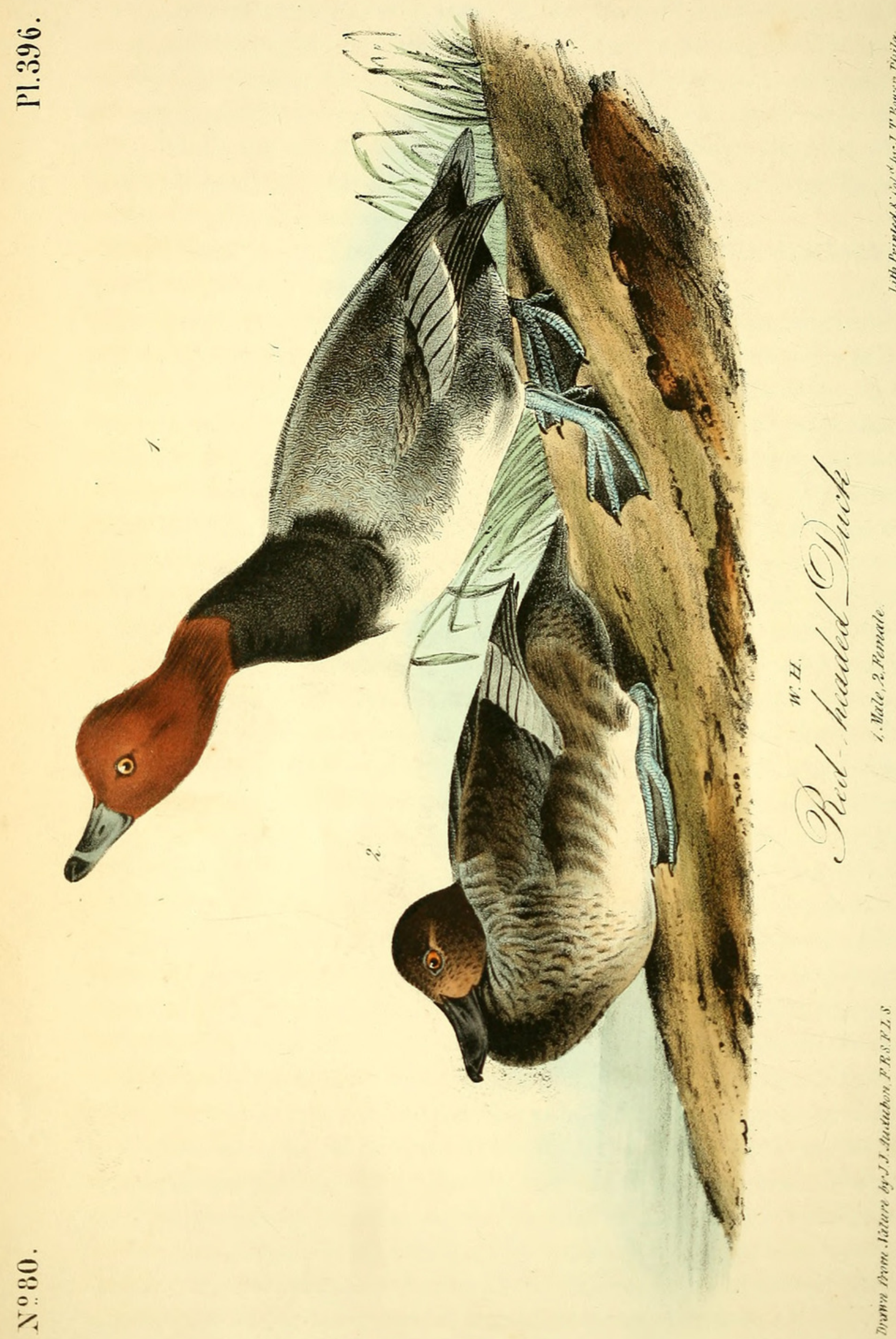




\section{$2 \mathrm{BHL}$ Biodiversity Heritage Library}

Audubon, John James. 1843. "Red-Headed Duck, Fuligula ferina, Linn. [PI. 396]." The birds of America : from drawings made in the United States and their territories 6, 311-315. https://doi.org/10.5962/p.319509.

View This Item Online: https://www.biodiversitylibrary.org/item/124857

DOI: https://doi.org/10.5962/p.319509

Permalink: https://www.biodiversitylibrary.org/partpdf/319509

\section{Holding Institution}

Smithsonian Libraries

\section{Sponsored by}

Biodiversity Heritage Library

\section{Copyright \& Reuse}

Copyright Status: NOT_IN_COPYRIGHT

This document was created from content at the Biodiversity Heritage Library, the world's largest open access digital library for biodiversity literature and archives. Visit BHL at https://www.biodiversitylibrary.org. 